\title{
Hurricane pounds Florida research facilities
}

More than 4,000 research primates were among the homeless after Hurricane Andrew destroyed parts of southern Florida last week. Winds as high as 160 miles an hour blew apart hundreds of cages holding more than 400 rhesus monkeys and baboons at one National Institutes of Health (NIH) facility and flattened a commercial primate breeding facility that contained an estimated 4,000 animals.

At the NIH facility, operated by the University of Miami, about 10 per cent of the animals were killed when the cages "exploded" and the high winds "basically turned the monkeys into birds", says Robert Rubin, vice president for research at the University of Miami. Those that survived soon faced other dangers. An erroneous radio account reported that the monkeys were infected with the HIV virus and were biting people, and Coast Guard troops at a nearby installation began shooting the monkeys out of the trees in which they had taken shelter. In the 30 minutes that it took officials at the NIH Perrine facility to correct the report (the animals were in fact bred to be virus-free) six monkeys had been killed.

A nearby commercial facility, owned by the Mannheimer Foundation, reportedly suffered even more serious damage. Telephone contact with the facility was impossi- ble late last week, but Rubin says that initial reports indicated that the facility was heavily damaged and about 4,000 primates were on the loose, with an unknown number killed or seriously injured.

Collecting the animals turned out to be another challenge. National Guard troops were called in after reports of baboons foraging in the streets - citizens were warned not to approach them and to drop any food they might be holding to avoid fights with the animals - but chasing the animals proved futile. Eventually, facility staff hit upon the best solution: put some monkey chow in an open cage and wait. Capturing most of the animals turned out to be as simple as shutting the cage doors, Rubin says.

Other research facilities in Florida were less hard-hit by the storm. Florida International University suffered about $\$ 5$ million in damage to several buildings and the Coral Gables campus of the University of Miami also reported significant damage. The storm cost the University of Miami between \$1 million and $\$ 2$ million.

Perhaps the most significant impact of the storm is the time that researchers have lost. The University of Miami reported that at least 200 research staff had lost their homes. Although no one was killed, "we're all still shell-shocked", said one university spokeswoman. Experiments at the Perrine facility are expected to be delayed for six months as staff attempt to rebuild the breeding stock.

Damage to marine research fleets based in southern Florida was largely averted by a decision to sail the vessels northwards. One 36-foot sailboat belonging to the University of Miami was carried some 1.5 miles inland by storm-driven waves. Several shore buildings associated with the marine and oceanographic programmes lost parts of their roofs and roof-mounted equipment, including antennae, satellite dishes and laser gear.

The National Aeronautics and Space Administration (NASA) has delayed the launch of its Mars Observer mission after an operation to protect the spacecraft from the hurricane accidentally contaminated it. NASA said that the launch, scheduled for 16 September, would be delayed by at least 10 days while technicians cleaned the craft. Tests revealed that technicians had inadvertently sprayed paint and metal fragments on to the craft when they piped impure nitrogen into the Titan 3 nose cone to guard against fires caused by storm-related electrical sparking. NASA officials said that the probe must be launched by 13 October to reach Mars on schedule in September 1993.

Christopher Anderson

\section{Academy says US national parks need more research}

Washington. Insufficient research at US national parks has led to dozens of mistaken decisions and ecological disasters, a US National Academy of Sciences (NAS) panel has concluded in a report* released last month. Decrying decades of poorly funded research, the NAS panel called for a separate category for science in the National Park Service budget as a way to end the practice of diverting research funds for other purposes.

The new review is at least the twelfth major report since 1963 to comment on the sorry state of research in the US national parks and the need for better science. But panel members hope that it will be more influential than its predecessors, in part because wildlife management decisions are increasingly the subject of litigation. Park Service officials, realizing that better research data can improve their chances of victory in court, have endorsed the conclusions of the NAS report.

The NAS report, like many of the previous reviews, points out that the Park Service has one of the smallest percentages of researchers of any federal agency. Only in the past year has the Park Service significantly increased its research staff, from 48 to 112 scientists, and even the current number represents only 3 per cent of its staff. The figure is $8-10$ per cent at other US land management agencies.

Panel members blamed many of the Park Service's most notorious instances of mismanagement of plants, animals and natural resources on its historic disregard of science. The report cites cases where wellmeaning park rangers killed wolves, bears, coyotes and other natural predators while they fed more 'desirable' species such as deer and elk. Only when the growing number of protected animals began to eat their way through the parks did the managers realize the consequences of such interference with the natural equilibrium. Similarly, in the absence of research on the subject, park rangers for decades suppressed natural fires until it became obvious that small fires are essential in controlling undergrowth and preventing catastrophic forest fires.

Today, the Park Service must decide how to maintain natural equilibria while allowing increasing numbers of visitors to visit the parks. Some parks have already begun to limit attendance, but there is no research to suggest that response is the best approach.

The NAS report calls for an "explicit mandate" - including a distinct line-item funding category — for science in the Park Service. It also recommends a new position

\section{IMAGE UNAVAILABLE FOR COPYRIGHT REASONS}

\section{Are power plants the source of this haze over the Grand Canyon?}

of chief scientist and an external scientific advisory board. Christopher Anderson

* Science and the National Parks, National Academy Press, 1992 (2101 Constitution Avenue NW, Washing. ton, DC 20418). 